\title{
粘質土壤飞打ける茶園の造成法
}

静岡県西遠農業センター 井狩 寅三 郎

\section{1 はしがき，}

最近，茶業はかなり好況にめぐまれ，果樹等に比べ, かなり高い收益性が得られるため茶園の新植, 改植が進 んでいる。なかでも，新植の場合は，10ha以上いった 大きな規模で開慜，定植されている。しかし，いずれも 不良土壤あるいは傾斜地が多いので, 開園方法, 土墥保 全などいずれも問題点が多い。茶樹の生育は土壤の物理 性仁大きく左右されることはすでに知られているとおり であり，なかでも，土壤の通気性（排水性）は大きな影 響をるっている。われわれは粘質士壤で通気性のわる い, 三方原土壤に打いて, 昭和37年から, 特に土壌の改 良といら面から，大型機械に上る茶園の造成について調
查を行なってきたのでその概要を報告する。

2 開檠（耕起, 土壤改良, 整地) 調査

2 . 1 耕起 (深耕) 作業：ブルドーザーとレーキド ーザ（いずれも11トン）を使用し，1区44.5 a，2連制

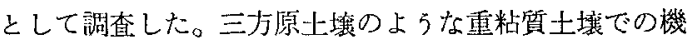
械耕起の能力, 能率は表 1 に示したよ5に,ブルドーザ では89〜96cmの能力があり，レーキドーザでは72.5〜93 cmの能力で, ブルドーザによる三段耕起のほうが澡く耕 起ができた。

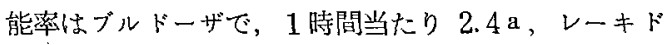
一ザで $4.3 \mathrm{a}$ で, レーキドーザがブルドーザに比べ約 2 倍の能率があげられる。

表 1 耕起能力, 能率比較調查

\begin{tabular}{|c|c|c|c|c|c|c|c|c|c|}
\hline 能力率 & & & の & 深 & さ & & 10际 & たり亩 & a \\
\hline 機械名 反復。 & I & II & ' III & IV & $\mathrm{V}$ & 平 均 & I & II & 平均 \\
\hline ブルドーザ & 96 & 89 & 91 & 96 & 93 & 93.0 & 2.3 & 2.5 & 2.4 \\
\hline レーキドーザ & 93 & 80 & 72.5 & 76 & 81 & 80.5 & 4. 2 & 4.4 & 4.3 \\
\hline
\end{tabular}

また，耕起に上る土の移動はその後の茶樹の生育に影 響を及ばすと考えられるので，装層土塂の移動について 調查した結果が表 2 である。

\section{表 2 表層土壤の移動}

\begin{tabular}{|c|c|c|}
\hline 機械名 項 目 & 水平移動 & 垂直移動 \\
\hline ブル、ドーザ & $300 \sim 400^{\text {cm }}$ & $50 \sim 70{ }^{\mathrm{cm}}$ \\
\hline レーキドーザ & $180 \sim 270$ & $20 \sim 40$ \\
\hline
\end{tabular}

ブルドーザ耕起は三段耕起を行な5ため，表層土の移 動が水平，垂直移動ともに大きく，下層土が表面に出て くるため，土镍改良がより以上にできると考えられる。 しかし、レ一キドーザでは水平, 垂苜移動ともに少なく なっており，あをり，表層土が移動しない。

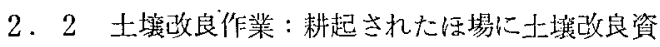
材として鶚永ん，炭力ル，苦土石网を施用し，その作業 について調查した結果は表了に示すとおりで，耕起され た湯に穒怘んを施用した能率は10 a 当り $600 \mathrm{~kg}$ 施用す るのに男 1.1 人が必要であったが，これは耕起された㣪 のまだ砕土の行なわれていない場であるため，作業能
表 3 土壤改良作業

\begin{tabular}{|c|c|c|c|}
\hline 項目 & 鷄 S. & 湠力ル & 苦土石灰 \\
\hline 施 & $600 \mathrm{~kg}$ & $200 \mathrm{~kg}$ & $200 \mathrm{~kg}$ \\
\hline $\begin{array}{l}\text { 率 } \\
(10 \text { ア }\end{array}$ & 人力 & $\begin{array}{l}\text { ライムソ } \\
-7 \text { 分 }\end{array}$ & $\begin{array}{l}\text { ライムУ了 } \\
-\quad 5 \text { 分 }\end{array}$ \\
\hline
\end{tabular}

率が孯く，また施用された鶏らんがその後の砕土によ。 ても表㬝のみにとどまり，下層までの土燷改良にはなら ない。(耕起前には篗草の発生が多く，施用作業が非常 に困䧼であったために耕起後に施用した。っこのためや はり，耕起前に雑学を除き施用すれば，下層まで改良さ れ，また作業能率ももっと向上するものと考えられる。 嵌カルと苦士石成の施用作背の能率は非常に良く，炭力 ルに比べ苦土石网の能率が良いのは主として苦土石灰の 比重が大きく，ライムソアーの 1 回の積載量が多いため である。

2.3 整地 (砕土) 作業: 大型機械で耧起された後 に砕土を主とする整地作業がある。この調查はレーキド 一ザで耕起された揚をディスクハローで荒碎土を行な い,ざらにロータベータで中砕土を行なった時に調查し 
た結果は表 4 に示すとおりである。

\section{表 4 碎土能率比較}

\begin{tabular}{|c|c|c|}
\hline 作業名 項 & 砕土の種類 & $10 \mathrm{a}$ 当り能率 \\
\hline ディスクハロー & 荒砕 土 & 7分30耖 \\
\hline ロータベータ & 中 砕 土 & 27 分 \\
\hline 人 & 荒中䂽士 & 400封間 \\
\hline
\end{tabular}

最初にディスクハロー（18連式）で，荒碎土を行なっ た能率は土壤の凍結により作業が最良の状態で行なえな かったが10a当たり7分30秒，つづいてローターベータ で中砕土を行なった，この所要時間は 10 a 当たり 27 分で ありこの二つの作業で，おおまかな础土が行なえるの であるが，人力では $10 \mathrm{a}$ 当たり 400 時閒であった。

\section{3 暗きょ排水}

粘質土塆であり，80〜100 cm のところに堅い盤層があ り，排水がきわめて悪く土識調査のため; ボーリングし
た跡に 1 週間以上も滞水しているよ5な状態であるの で，ほ場の周柬はもちろん明きょの排水路を設けたが， '汪場内には，20m間隔に農道の下に暗きょ排水路を設け

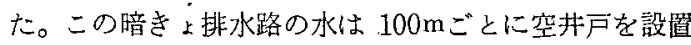
してこれに集水する。構造は図 1に示すとおりである。

暗きょ排水の 效果を判定するのは非常に困難である が，降水量との関係は表5に示したとおりで，1日の降 水量が30 m的以下の場合には全然変化か認められないが, 40mm程度になると，多孔管にしみ出るよ5になり，50 $\mathrm{mm}$ 以上になると少し流れる。また，60 min上上になると，空 井戸に集水される。地表面の 滞水は，150m くらいの降 水量でも2 日以上は滞水しなかった。

表 5 排 水 效 果

\begin{tabular}{|c|c|c|c|c|c|c|}
\hline $\begin{array}{l}\text { 陫水施設設 } \\
\text { 諻mm }\end{array}$ & 20以下 & 30 & 40 & 50 & 60 & 70以上 \\
\hline 多孔管 & - & - & しみ出 & 少し流 & 流れ出 & 流机出 \\
\hline 空井戸 & - & - & - & しみ出 & 集水 & 集水 \\
\hline
\end{tabular}

4 耕 起 方 法

静阙県の場合, 茶園では改植を 淮めるためレーキドーザ，みかん 園では新植が抢もなためブルドー ザが主に導入されているが，この 2 つの開䛻方法の効果について检 討した。

4. 1 活着：標準方法で定植 した場合の活着状況は表 6 に示す とおりである。
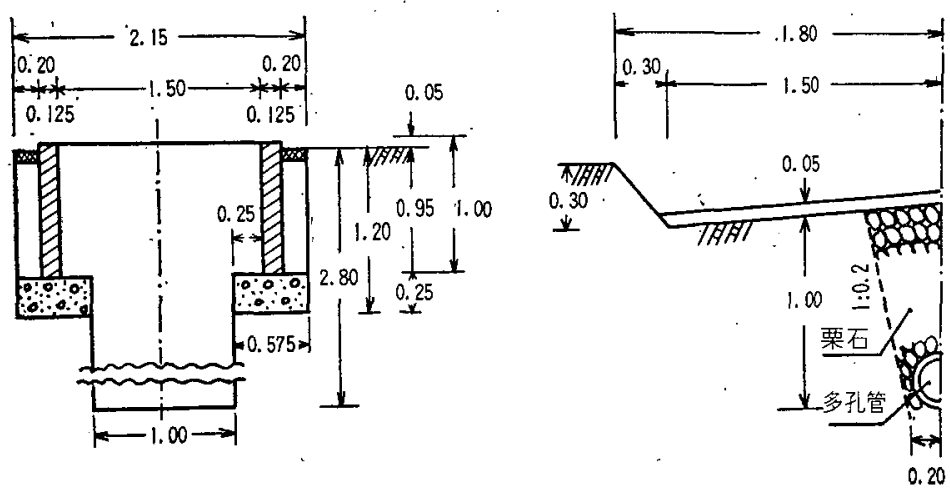

\begin{tabular}{|c|c|c|c|c|c|c|c|c|c|c|c|}
\hline \multirow{3}{*}{\multicolumn{3}{|c|}{ 耕起力法 }} & 斐 & 活 & 着 & $7:$ & & 沉 & & & \\
\hline & & & \multicolumn{3}{|c|}{ 7. 25} & \multicolumn{3}{|c|}{ 12. 19} & \multicolumn{3}{|c|}{ 3. 20} \\
\hline & & & 活着怢 & 枯㱜侏 & 活清率 & 活着株 & 枯死株 & 活着率 & 活着株 & 枮死株 & 活着率 \\
\hline \multirow{2}{*}{ ブルドーザ } & 大 & 苗 & $588^{\text {株 }}$ & $72^{\text {株 }}$ & $89.1^{\% /}$ & $571^{\text {株 }}$ & $89^{\text {株 }}$ & $86.4^{\%}$ & $565^{\text {株 }}$ & $95^{\text {株 }}$ & $85,5^{\%}$ \\
\hline & 標＼cjkstart準 & & 292 & 368 & 44.1 & 276 & 383 & 41,8 & 210 & 450 & 31,8 \\
\hline \multirow{2}{*}{ レーキドーザ } & 大 & 苗 & 585 & 75 & 88,5 & 568 & 92 & 86,0 & 558 & 102 & 84.6 \\
\hline & 標 準 & 苗 & 617 & 43 & 93.5 & 610 & 50 & 92.5 & 567 & .92 & 85.9 \\
\hline
\end{tabular}

注：大苗 (ベにほまれ，仮植 5 年生), 標準苗 (はつむみじ,ささい木 3 年生) 
大苗では，耕起による差はほとんど認められない。し かし，標準苗ではレーキドーザ耕起が圧倒的に良く，大 苗と汪とえど变わらないが，ブルドーザ耕起は 3 割程度 の活着率しか示さながった。これは特にブルドーザ耕起 は表層土境の理化学性を悪くするためすくくに比較的抵 抗力の少い標準苗を植付ける場合の一つの大きな問題点 となると考えられる。
4. 2 生育 : 生育状況は表 7 に示すとおりで, 2 年 生までは自然仕立であり，樹高，株張りともにブルドー ザ耕起がやや良かったが，3年生からは機械摘みのた め，せん枝を行ならので，樹高ではあまり差が認められ ない。しかし、株張りではブルドーザ耕起がややすぐれ ていた。

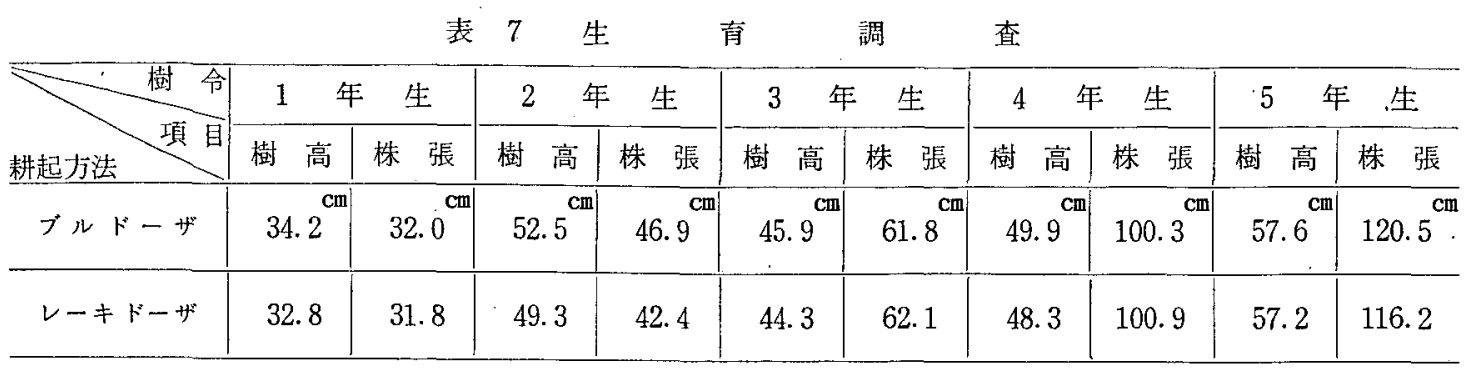

4. 3 収量: 耕起方法の占がいが䒩収量におよぼす 影響について調查したのが表 8 であり，3年生ではブル ドーザ耕起が多かったが，4 年生から 5 年生まではレー
キドーザが多くなり，6年生では医とんど差がなく，耕 起方法による収量差はあまり認められなかった。

表 8 樹粭別にみた収量（10 a 当）

\begin{tabular}{|c|c|c|c|c|c|c|c|c|c|}
\hline 樹 命 & 3 年 生 & 4 年 & 生 & 5 & 年 & 生 & 6 & 年 & 生 \\
\hline 耕起方法 荼其 & 一番茶 & 一番茶 & 二璠茶 | & 一番茶 & 二番茶 & 三番茶 & 一番茶 & 二番茶 & 三番茶 \\
\hline ブルドーザ & $172.5^{\mathrm{kg}}$ & 290.0. & $172.6^{\mathrm{kg}}$ & $308.8^{\mathrm{kg}}$ & $200.0^{\mathrm{kg}}$ & $220.0^{\mathrm{kg}}$ & $352.5^{\mathrm{kg}}$ & $232.5^{\mathrm{kg}}$ & $275.3^{\mathrm{kg}}$ \\
\hline レーキドーザ & 154.4 & 317.0 & 193.6 & 318.8 & 202.4 & 232.4 & 350.6 & 243.6 & 262.5 \\
\hline
\end{tabular}

4.4 地力: まえにも述べたよ5に, 耕起方法のち がいは, 土境の物理化学性に大きな影響を持ち, 結果と して地力も異なり茶樹の生育を左右すると考えられるの
でこの関係を黒干石大至をもちいて調査した結果を示 すと表 9 とおりである。

表 9 地力調 查 (黑千石, 無肥栽培)

\begin{tabular}{|c|c|c|c|c|c|c|c|}
\hline 年 次 & 第 & 1 年 & 次 & 第 & 年 次 & 第 & 年 次 \\
\hline 耕起方法 & 草文 & 分 枝 数 & 1 株䖝乾重 & 草 丈 & 分 枝 数 & 草文 & 分 枝 数 \\
\hline ブルドーザ & $89.3^{\mathrm{cm}}$ & $8.27^{\text {本 }}$ & $45.3^{g}$ & $88,5^{\mathrm{cm}}$ & $7.29^{\text {本 }}$ & $80.5^{\mathrm{cm}}$ & $7.1^{\text {本 }}$ \\
\hline レーキドーザ & 104.6 & 8.02 & 40.3 & 87.2 & $7.50^{\circ}$ & 79.8 & 7.3 \\
\hline
\end{tabular}

注：連作

大豆（黒干石）は 3 年連作を行なったが， 1 年目は草 丈ではレーキドーザが良く, 分枝数, 風乾垂に打いては ブルドーザがすぐれており，あまり，差がなかった。2 年目，3年目になっても連作であるため，全般に生育は 悪くなってくるが, 耕起の違いによる差は汪とんどみと
められなかった。

4. 5 雑草の発生量: 耕起方法のちがいは, 土壤 （特に表居土）の移動がかなり異なるため，当然耕起後 の雑草の繁茂も買なると教えら机るので調查を行なった が，結果は表10のとおりである。レーキドーザ耕起の場 


\begin{tabular}{|c|c|c|c|c|c|c|c|c|c|c|c|c|c|c|c|}
\hline 年 次 & 1 & & 年 & 2 & & 年 & 3 & & 年 & 4 & & 年 & 5 & & 年 \\
\hline 耕起方法 項目 & $\begin{array}{l}\text { 発告数 } \\
\end{array}$ & $\begin{array}{l}\text { 多年 } \\
\text { 生 }\end{array}$ & 正年 & $\begin{array}{l}\text { 発生 } \\
\text { 数 }\end{array}$ & $\begin{array}{l}\text { 多年 } \\
\text { 生 }\end{array}$ & 正 & 発生数 & $\begin{array}{l}\text { 多年 } \\
\text { 生 }\end{array}$ & 一年 & $\begin{array}{l}\text { 発生 } \\
\text { 数 }\end{array}$ & $\begin{array}{l}\text { 多年 } \\
\end{array}$ & \begin{tabular}{|l|} 
年 \\
生
\end{tabular} & $\begin{array}{l}\text { 発生 } \\
\text { 体数 }\end{array}$ & \begin{tabular}{|l|} 
多年 \\
生
\end{tabular} & 正年 \\
\hline ブルドーザ & 216 & 8 & 208 & 293 & 19 & 274 & 422 & 3 & 419 & 676 & 12 & 664 & 572 & 24 & 548 \\
\hline レーキドーザ & 322 & 21. & 301 & 451 & 43 & 408 & 410 & 18 & 392 & 584 & 16 & 568 & 668 & 20 & 648 \\
\hline
\end{tabular}

注 : 多年生雑草 : チガヤ, ムラサキカタバミ, ササなど, 1 年生雑草：メヒシバ,イヌビエ、イヌタデなど $4 \mathrm{~m}^{2}$ 内数, 調查はいずれも 8 月

4. 6 土壤の物理性：耕起方法の違いは，表層土の 移動など，土壤の物理性が大きく変ると考えられるので いずれも，9月に実容皘法で調查したが，結果は表11に 示すとおりである。1年目から 3 年目までは，ブルドー
ザ耕起の固相，液相ともにやや多く，気相，孔隙量が少

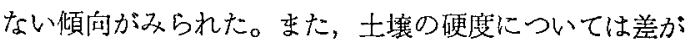
みられなかった。

表 11 土壤 の物理性の変化

\begin{tabular}{|c|c|c|c|c|c|c|c|c|c|c|c|c|c|c|c|c|}
\hline \multirow{2}{*}{\multicolumn{2}{|c|}{ 耕起深項 }} & \multicolumn{2}{|r|}{1} & \multicolumn{3}{|l|}{ 年 } & \multicolumn{2}{|r|}{2} & 年 & \multicolumn{2}{|l|}{ 目 } & \multicolumn{2}{|r|}{3} & 年 & \multicolumn{2}{|l|}{ 目 } \\
\hline & & 固相 & 液相 & 気相 & $\begin{array}{l}\text { 孔げ } \\
き\end{array}$ & 硬度 & 固相 & 液祖 & 気相 & $\begin{array}{l}\text { 孔げ } \\
\text { ぎ }\end{array}$ & 硬度 & 固相 & 液相 & 気相 & $\begin{array}{l}\text { 孔げ } \\
\text { き }\end{array}$ & 硬度 \\
\hline \multirow{3}{*}{ ブルドーザ } & $\begin{array}{c}\mathrm{cm} \\
0 \sim 20\end{array}$ & 37.5 & 28.2 & 35.3 & 63.5 & 12.2 & 38.5 & 28.5 & 33.0 & 61.5 & 13.4 & 39.9 & 25.8 & 34.3 & 60.1 & 12.3 \\
\hline & $20 \sim 40$ & 34.5 & 26.5 & 39.0 & 65.5 & 16.5 & 37.0 & 29.0 & 34.0 & 63.0 & 16.8 & 39.0 & 28.0 & 33.0 & 61.0 & 17.4 \\
\hline & $40 \sim$ & 35.0 & 29.0 & 36.0 & 65.0 & 16.2 & 35.3 & 29.5 & 35.2 & 64.7 & 17.0 & 35.5 & 29.8 & 34.7 & 64.5 & 17.1 \\
\hline \multirow{3}{*}{$\begin{array}{l}\text { レ゙ーキドー } \\
\text { ザ }\end{array}$} & $0 \sim 20$ & 36.5 & 23.4 & 40.1 & 63.5 & 13.3 & 36.0 & 24.0 & 40.0 & 64.0 & 13.7 & 36.6 & 22.2 & 41.8 & 63.4 & 15.6 \\
\hline & $20 \sim 40$ & 35.5 & 28.2 & 36.3 & 64.5 & 16.5 & 36.5 & 23.5 & 40.0 & 63.5 & 17.0 & 37.5 & 25.5 & 37.0 & 62.5 & 17.3 \\
\hline & $40 \sim$ & 36.8 & 27.6 & 35.6 & 63.2 & 16.0 & 36.7 & 24.5 & 38.8 & 63.3 & 16.5 & 36.7 & 27.8 & 35.5 & 63.3 & 16.3 \\
\hline \multirow{2}{*}{\multicolumn{2}{|c|}{ 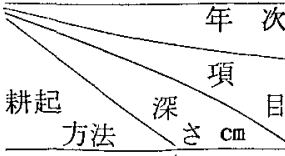 }} & & 4 & 年 & 目 & & & 5 & 年 & 目 & & \multirow{2}{*}{\multicolumn{5}{|c|}{$\begin{array}{r}4 \text { 年目からは，耕起によ } \\
\text { る差ははとんどみられなく }\end{array}$}} \\
\hline & & 固相 & 液相 & 気相 & $\begin{array}{l}\text { 孔げ } \\
き\end{array}$ & 硬度 & 固相 & 液相 & 氮相 & $\begin{array}{l}\text { 孔げ } \\
き\end{array}$ & 硬度 & & & & & \\
\hline \multirow{3}{*}{ ブルドーザ } & $0 \sim 20$ & 34.5 & 27.2 & 38.3 & 65.5 & 12.5 & 36.5 & 29.6 & 34.9 & 64.5 & 13.8 & \multirow{3}{*}{\multicolumn{5}{|c|}{ 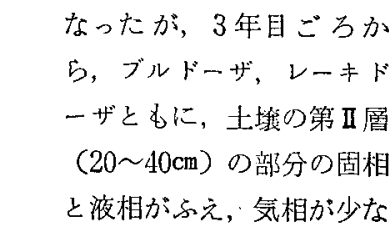 }} \\
\hline & $20 \sim 40$ & 39.5 & 29.5 & 31.0 & 60.5 & 14.9 & 37.8 & 32.5 & 29.7 & 62.2 & 17.8 & & & & & \\
\hline & $40 \sim$ & 35.5 & 29.8 & $34: 7$ & 64.5 & 17.3 & 35.6 & 28.6 & 35.8 & 64.4 & 16.5 & & & & & \\
\hline \multirow{3}{*}{$\begin{array}{l}\text { レーキドー } \\
\text { ザ }\end{array}$} & $0 \sim 20$ & 35.5 & 28.5 & 36.0 & 64.5 & $\cdot 12.3$ & 36.5 & 28.6 & 34.9 & $63.5 \mid$ & 13.2 & \multirow{2}{*}{\multicolumn{5}{|c|}{$\begin{array}{l}\text { くなり，これに伴って孔げ } \\
\text { き量が少なくなる傾向が徐 } \\
\text { 々に現われてきた。 }\end{array}$}} \\
\hline & $20 \sim 40$ & 39.5 & 29.5 & 31.0 & 60.5 & 18.5 & 39.6 & 29.7 & 30.7 & 60.4 & 17.8 & & & & & \\
\hline & $40 \sim$ & 37.5 & 27.5 & 35.0 & 62.5 & 16.5 & 38.3 & 27.5 & $34: 2$ & 61.7 & 14.5 & & & & & \\
\hline
\end{tabular}


5 定植

5. 1 改良資材の投入方法：土壇改良资材を定植時
に有効に使用するため表12のよらな施用方法を行ない， 定植した場合の結果は表13のとおりで女る。

表 12 土裁改良資材の投入方法

\begin{tabular}{|c|c|c|c|c|}
\hline 施用力 & & 処 & 理 & 法 \\
\hline 混 & 施 & コンポスト $4.5 \mathrm{t}$, 鶏灾え $0.25 \mathrm{t}$, & 石灰0.2t 学作条に施用し， & 中型トラクターで浘層 \\
\hline 条 & 施 & 中型トラクターで作条 $($ 深さ30cm) & ししこれにコンポスト $4.5 \mathrm{t}$, & 鵄ふん0. $25 \mathrm{t}$ ，石灰 $0.2 \mathrm{t}$ を施用 \\
\hline
\end{tabular}

表 13 有機資材の施用方法と茶樹の生青

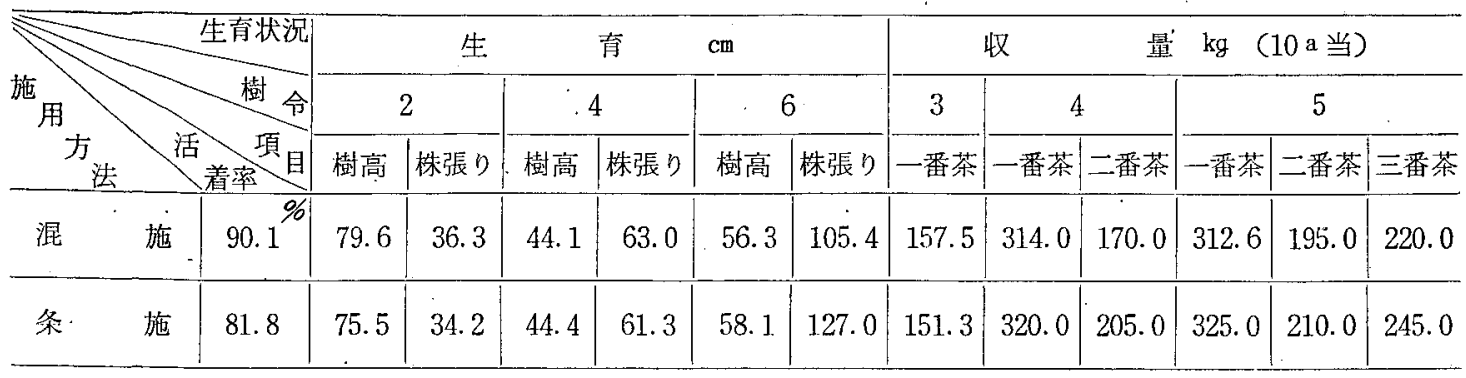

活着状沇は混施の方が条施に比べ成績がよかった。生 育状況は 4 年生ぐらいまでは混施のほうがすぐれていた が，その後は条施の方が生育がよくなった。収量は， 3 年生では混施の方が多かったが，樹踹が大きくなるにつ れ，条施の方が多くなってきた。条施の場合は活着と早 期 (若跲) の生育は劣るがその後は生育が良くなるの で，今後はさらに早期の生育を良くするための力法を用 いなければならない。

5.2 苗木の大きさ：機械開塱後の茶樹の移植方法 としての苗木の大きさについて調查するため表14のよ゙う な茶樹を定植したが，調查結果は表15のとおりである。
表 14 定植時にお忛る茶樹の状態

\begin{tabular}{|c|c|c|c|c|c|}
\hline & 茶 樹 & の重 & & & \\
\hline 験 区別 & 総重量 & $\begin{array}{l}\text { 地上 } \\
\text { 部重 }\end{array}$ & 根重 & & \\
\hline 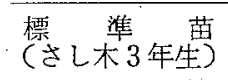 & $\begin{array}{r}g \\
22.5\end{array}$ & $\begin{array}{r}g \\
12.3\end{array}$ & $\begin{array}{r}\bar{g} \\
10.2\end{array}$ & 1.20 & 11 \\
\hline (仮植 3 年生) & 49.6 & 26.5 & 23.1 & 1.14 & 16 \\
\hline 大(仮植 5 年生) & 235.9 & 120.4 & 115.5 & 1.04 & 29. \\
\hline 成 & $1,467.5$ & 623.9 & 843.6 & 0.73 & 28.3 \\
\hline
\end{tabular}

表 15 苗木の大きさと生育

\begin{tabular}{|c|c|c|c|c|c|c|c|c|c|c|c|c|c|}
\hline \multirow{3}{*}{\multicolumn{2}{|c|}{ 苗 }} & \multirow{2}{*}{\multicolumn{2}{|c|}{ 生 }} & \multicolumn{2}{|c|}{ 育 } & \multicolumn{2}{|l|}{$\mathrm{cm}$} & \multicolumn{3}{|c|}{ 収 } & \multicolumn{3}{|c|}{ 量 $\mathrm{kg}(10 \mathrm{a}$ 当 $)$} \\
\hline & & & & 4 & & 6 & & 3 & 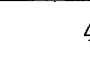 & 4 & & 5 & \\
\hline & & 樹高 & 株钱り & 樹高 & 株張り & 樹高 & 株張り & 一番茶 & 一番茶 & 二番茶 & - - 番茶 $\mid$ & 二番茶 & 三番茶 \\
\hline 標 準 苗 & 53.3 & 56.5 & 28.5 & 43.3 & 63.7 & 49.4 & 91.4 & 41.2 & 80.2 & 65.2 & 102.6 & 175.0 & 63. \\
\hline 苗 & 88.6 & 76.3 & 45.8 & 49.5 & 91.4 & 54.9 & 121.1 & 122.3 & 248.8 & 193.8 & 265.0 & 461.2 & 123. \\
\hline 大 & 88.9 & 64.5 & 42.4 & 49.8 & 97.8 & 54.8 & 121.6 & 132.5 & 273.8 & 228.8 & 312.6 & 468.8 & 140. \\
\hline 成 & 100.0 & 75.2 & 63.6 & 53.5 & 106. 1 & 57.5 & 130.8 & 234.2 & 406.4 & 352.6 & 520.0 & 512.5 & 271.9 \\
\hline
\end{tabular}

まず，活着についてみると，苗木が大きくなるにつ れ，活着率がよくなったが，中苗と大苗ではあまり差が
認められなかった。

生育状態は活着率と同じょうに苗の大きさと関係があ 
り，苗不が大きくなるにつれ，生育もよくなった。しか

し,中苗と大苗ではあまり差が認められなかった。。收量 についても，活着や生育と同じ上5に苗木が大きくなる につれ収量も多くなったが，中苗と大苗ではあまり差が なかった。この上らなことから考えて, 機械開墾後の苗 木は实用面から教えて; 仮植 3 年くらいの苗木が最適だ と考えられる。
6 ๘ め

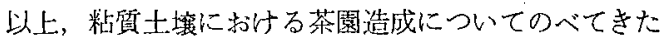
か゚，粘質土堙で一番問題になるのは土壤の物理性であ ると考えられる。しかし，現在までのところ，物理性は 良好であるが，まだ試験調查年次も短かく不明な点が多 く，今後はさらにこの点について検討する必要がある。

改植時の土壤処理および

その後の肥培方法が茶の生育、品質に及ぼす影響

茶業試験場杉井四郎・青野英也・田中静夫 築瀬好充・吉川 茂

茶の改植に当たっては，定植苗の樹勢を強め，できる だけ末成木期間を短縮し，かつ，その後の生産力もより おう盛にし得る土壌改良方法, あるいはその後の肥培管 理方法の採用が必要であると考えられる。

演者らはこれらの適確な方法を確立するために，1961 年1 2月，表首の深さ約 $20 \mathrm{~cm}$ までが黒ボクで，その下層 に赤土を有する場内洪皘層土壤の在来種茶園を抜根し,

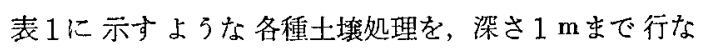
い, 直径 $1 \mathrm{~m}$, 深さ $1 \mathrm{~m}$ のコンクリート製無底ポットに 各区4 個あて充てんした。その後, 約 1 年間は休閑し, 1962年 4 月にざにふじ 2 年生苗を 1 ポット当たり 5 本ず つ定植した。ざらにこれらの土壤炠理区を施肥量の多 少，およびたい肥施用の有然に 4 分割し，計16区の処理 区を設け，その生育状況を追跡した。

表 1 試験区の構成と処理方法

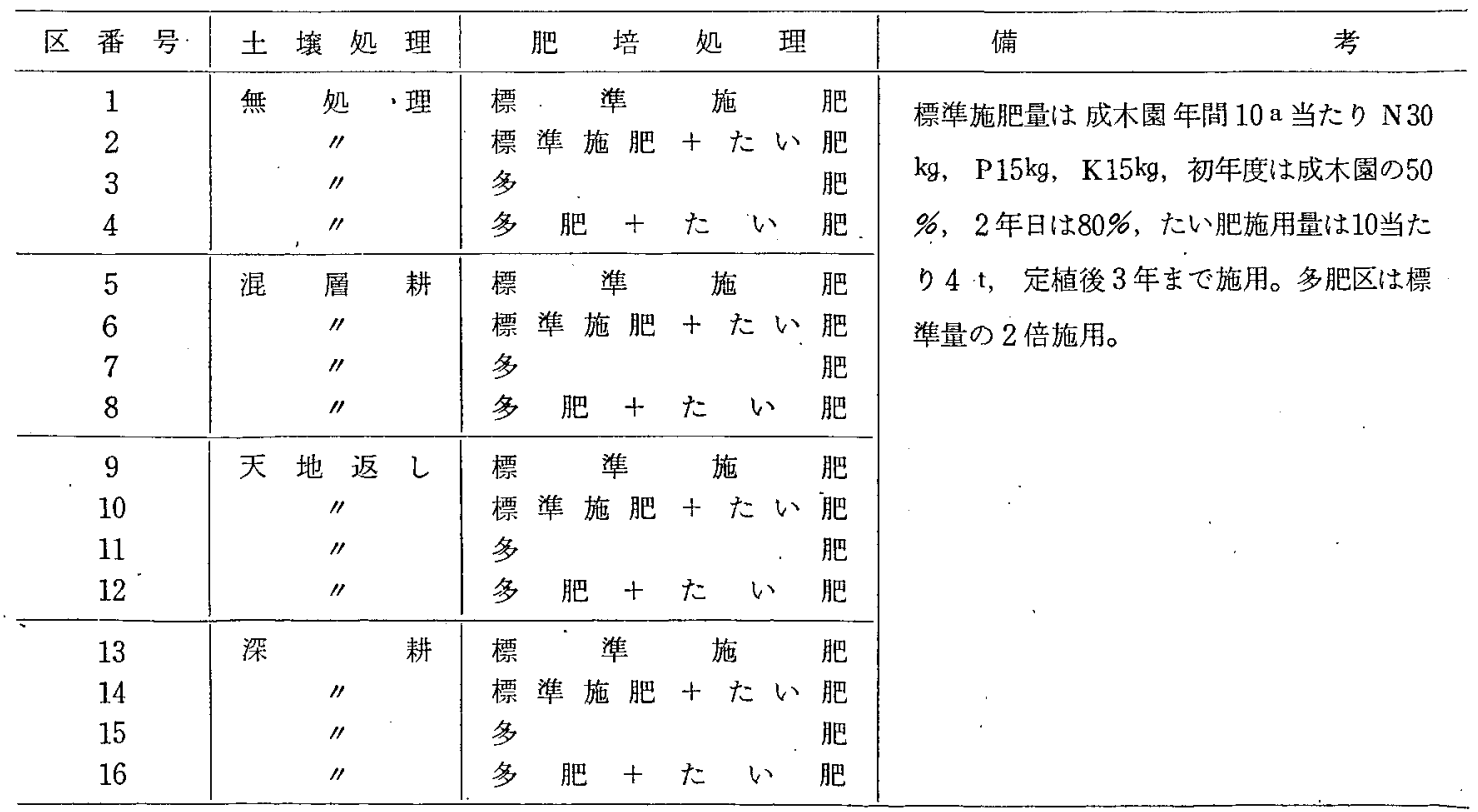

以上の処理により土壤の理化学的性筫が変化すること は当然であるが，土壌処理による物理性の変化につい
て，処理土壤の団粒分析を試みた結果は表 2 のごとくで ある，すなわち，処理による団粒部分は，混層耕，天地 
返し区など下層土が表層にでてくる活ど增加する傾向が むり，無処理区ないし深棒区に比較して，混層耕区では 2.9〜1.0nm㧍よび $0.4 \sim 0.25 \mathrm{~mm}$ の粒径部分が，天地返し 区では0.4〜0.25mおよび0.24〜0.1mu粒径部分が多く なっている。また処理土壇の寒容稳について調查した結 果は表 3 のごとくであり，気相容棹では天地返し区が最
も多く、深耕，混屏耕がこれにつぎ，無処理区は最も少 ない。また，固相，容嫧はほぼ気相とは逆の傾向を示し た。さらに肥培方法別ではたい肥施用の影響が みられ

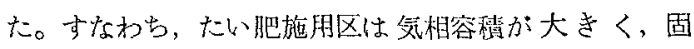
相, 液相容積はたい肥無施用区に比し $2 \sim 3 \%$ 少なかっ た。

表 2 土墥処理に上る団粒分布の変化（5１0 cm部位）（1962年 9 月）

\begin{tabular}{|c|c|c|c|c|c|c|c|c|}
\hline 㐐 理 区. & 径| & $3.0 \mathrm{~mm}>$ & $2.9 \sim 1.0 \mathrm{~mm}$ & $0.9 \sim 0.5 \mathrm{~mm}$ & $0.4 \sim 0.25 \mathrm{~mm}$ & $0.24 \sim 0.1 \mathrm{~mm}$ & $\begin{array}{c}\text { 計 } \\
\text { (寒用透過度) }\end{array}$ & $0.1 \mathrm{~mm}>$ \\
\hline 処 & 理 & $2.6^{\%}$ & $27.9^{\%}$ & $25.5^{\%}$ & $17.9^{\%}$ & $12.1^{\%}$ & $86.0^{\%}$ & $14.0^{\%}$ \\
\hline 層 & 耕 & 2.6 & 29.5 & 24.4 & 20.5 & 11.5 & 88.5 & 11.5 \\
\hline 天 地 返 & L & 2.6 & 26.5 & 24.0 & 22.2 & 14.3 & 89.6 & 10.4 \\
\hline 深 & 耕 & 2.7 & 23.8 & 24.1 & 16.4 & 12.7 & 79.7 & 20.3 \\
\hline
\end{tabular}

表 3 各処理による土壤実容績の変化

(5〜10 $\mathrm{cm}$ 部位)

A) 気 相 容 皘 (\%)

\begin{tabular}{|c|c|c|c|c|c|}
\hline 肥培処理 土壤処理 & 無処理 & 混層耕 & 返地 & 深耕 & 平均 \\
\hline 標 準 施 肥 & 37.3 & 44.2 & 46.0 & 42.2 & 42.4 \\
\hline 標肥たたい肥 & 44.5 & 46.4 & 48.3 & $46.0^{8}$ & 46.3 \\
\hline 多肥 & 34.8 & 44.2 & 43. 3 & 46.8 & 42.3 \\
\hline 多肥 十たい肥 & 34.8 & 45.0 & 47.2 & 47.0 & 46.0 \\
\hline & 40.4 & 45.0 & 46.2 & 45.5 & \\
\hline
\end{tabular}

B) 固相容皘 (\%)

\begin{tabular}{|c|c|c|c|c|c|}
\hline 肥培処理 土壤処理 & 無処理 & 混層耕 & 芺地 & 深耕 & 平均 \\
\hline 標 準 施 肥 & 33.4 & 29.3 & 29.2 & 30.8 & 30.7 \\
\hline 標肥 †たい肥 & 29.4 & 28.1 & 26.7 & 28.4 & 28.2 \\
\hline 多 & 33.4 & 28.9 & 29.3 & 27.1 & 29.7 \\
\hline 多肥 +たい肥 & 30.8 & 30.1 & 26.3 & 26.9 & 28.5 \\
\hline 均 & 31.8 & 29.1 & 27.9 & 28.3 & \\
\hline
\end{tabular}

C) 液 相 容稓 (\%)

\begin{tabular}{|c|c|c|c|c|c|}
\hline 肥培処理 土壇処理 & 無処珰 & 混層耕 & \begin{tabular}{|l} 
天地 \\
返し
\end{tabular} & 深耕 & 平均 \\
\hline 標 準 施 肥 & 29.3 & 26.5 & 24.8 & 27.0 & 26.9 \\
\hline 標肥 +たい肥 & 26.1 & 25.5 & 25.0 & 25.6 & 25.6 \\
\hline 多肥 & 31.8 & 26.9 & 27.4 & 26.1 & 28.1 \\
\hline 多肥 + たい肥 & 24.4 & 24.9 & 26.5 & 26.1 & 25.5 \\
\hline 平 & 27.9 & 26.0 & 25.9 & 26.2 & \\
\hline
\end{tabular}

以上の上5な土境処理によって，団粒部分が增加し， 気相容皘も大きく，土壤の物理性は向上した。さらに化 学性への影響は表 4 のでとくである。すなわち, 土壤処 理により下層士の湿入程度が增すにつれて, 置換酸度 $\mathrm{y}^{1}$ が大きくなり, 全窒素, 全炭素, 腐植, 有効態リン 酸，および置撸性石灰の各合量が少なくなり，肥よく度 は低下した。その後、秋の調查結果でもだいたい同じ傾 向であったが, $\mathrm{pH}$ は各区とも低く, 酸性が強くなり, 全炭素, 腐植を除いて他の含量は增加した。また肥培処

a) 定 植 前 (1962.4)

表 4 土塆処理による土墡化学性の変化

\begin{tabular}{|c|c|c|c|c|c|c|c|c|c|}
\hline 処 理 区 & $\begin{array}{c}\mathrm{pH} \\
\left(\mathrm{H}_{2} \mathrm{O}\right)\end{array}$ & $\begin{array}{c}\text { 置換酸度 } \\
\mathrm{Y}_{1} \\
\end{array}$ & 全窒素 & 全炭素 & $\mathrm{C} / \mathrm{N}$ & 鹰植 & $\begin{array}{l}\text { 当ン酸吸 } \\
\text { 収 俰数 }\end{array}$ & $\begin{array}{l}\text { 有効態 } \\
\text { 䈗 }\end{array}$ & 蹎換 趎 \\
\hline $\begin{array}{l}\text { 舞処 理 } \\
\text { 浱地返し } \\
\text { 深 耕 }\end{array}$ & $\begin{array}{l}5.7 \\
5.7 \\
5.6 \\
5.7\end{array}$ & $\begin{array}{l}0.8 \\
1.4 \\
3.1 \\
1.0\end{array}$ & $\begin{array}{l}0.17 \% \\
0.11 \\
0.02 \\
0.18\end{array}$ & $\begin{array}{l}3.18 \% \\
2.58 \\
1.58 \\
3.37\end{array}$ & $\begin{array}{l}18.8 \\
24.6 \\
65.8 \\
19.3\end{array}$ & $\begin{array}{l}5.48 \% \\
4.45 \\
2.72 \\
5.81\end{array}$ & $\begin{array}{l}931.9 \\
613.2 \\
372.3 \\
788.4\end{array}$ & $\begin{array}{l}6.1^{\mathrm{mg} \%} \\
3.0 \\
\operatorname{tr} \\
11.0\end{array}$ & $\begin{array}{c}208.3^{\mathrm{mg}} \% \\
168.0 \\
97.4 \\
173.6\end{array}$ \\
\hline
\end{tabular}

b) 定 植 後 (1962.9)

\begin{tabular}{|c|c|c|c|c|c|c|c|c|c|}
\hline $\begin{array}{l}\text { 無䞘 理 } \\
\text { 混層耕 } \\
\text { 夲地返し. } \\
\text { 耕 }\end{array}$ & $\begin{array}{l}4.7 \\
4.6 \\
4.6 \\
4.6\end{array}$ & $\begin{array}{l}8.4 \\
6.6 \\
6.6 \\
7.1\end{array}$ & $\begin{array}{l}0.22 \\
0.16 \\
0.06 \\
0.19\end{array}$ & $\begin{array}{l}4.17 \\
2.95 \\
1.29 \\
3.15\end{array}$ & $\begin{array}{l}19.0 \\
18.4 \\
21.5 \\
16.6\end{array}$ & $\begin{array}{l}7.18 \\
5.09 \\
2.23 \\
5.42\end{array}$ & $\begin{array}{r}1007.4 \\
761.8 \\
547.5 \\
754.7\end{array}$ & $\begin{array}{l}20.2 \\
21.9 \\
15.6 \\
22.7\end{array}$ & $\begin{array}{l}218.4 \\
300.7 \\
174.5 \\
259.3\end{array}$ \\
\hline
\end{tabular}


表 5 肥培処理による土裹化学性の変化 (1962年 9 月)

\begin{tabular}{|c|c|c|c|c|c|c|c|c|c|c|}
\hline 土壤処理 & 処理 & $\begin{array}{c}\mathrm{pH} \\
\left(\mathrm{H}_{2} \mathrm{O}\right)\end{array}$ & $\begin{array}{c}\text { 置換酸度 } \\
\mathrm{Y}_{1}\end{array}$ & 全窒素 & 全炭素 & $\mathrm{C} / \mathrm{N}$ & 腐 植 & $\begin{array}{l}\text { リン酸吸 } \\
\text { 収係 数 }\end{array}$ & $\begin{array}{l}\text { 有効態 } \\
\text { リン酸 }\end{array}$ & $\begin{array}{l}\text { 置換性 } \\
\text { 石 灰 }\end{array}$ \\
\hline & 標 準 施 肥 & 4.9 & 8.5 & $0.20 \%$ & $4.05 \%$ & 20.3 & $6.98 \%$ & 941.7 & $18.7^{\mathrm{mg} \%}$ & 184. $8 \mathrm{mgg}$ \\
\hline 無処理 & 標肥+たい肥 & 4.7 & 11.0 & 0.20 & 4.28 & 21.5 & 7.38 & 1314.0 & 18.7 & 112.0 \\
\hline 撗 & 多肥 & 4. 6 & 8.0 & 0.21 & 3.90 & 18.5 & 6.72 & 744.6 & 19.0 & 267.7 \\
\hline & 多肥十たい肥 & 4.6 & 6.1 & 0.26 & 4.43 & 16.9 & 7.64 & 1029.3 & 24.2 & 309.1 \\
\hline & 標 準 施 肥 & 4.6 & 4.7 & 0.13 & 2.51 & 19.6 & 4.33 & 744.6 & 15.5 & 248.6 \\
\hline 温展 琲 & 標肥+たい肥 & 4.7 & 6.3 & 0.15 & 2.70 & 17.6 & 4. 65 & 744.6 & 16.2 & 182.6 \\
\hline 沘 原 & & 4.5 & 9.5 & 0.18 & 3.30 & 18.5 & 5.69 & 769.4 & 18.7 & 225.1 \\
\hline & 多肥十たい肥 & 4.5 & 5.9 & 0.18 & 3.30 & 18.5 & 5.69 & 788.4 & 37.2 & 546.4 \\
\hline & 標準 施 肥 & 4.8 & 8.0 & 0.03 & 1.61 & 51.9 & 2.78 & 372.3 & 5.5 & 76.2 \\
\hline 天地汳 & 標肥+たい肥 & 4.5 & 11.0 & 0.11 & 1.24 & 11.5 & 2.14 & 766.5 & 5.7 & 60.5 \\
\hline & & 4.5 & 3.4 & 0.04 & 0.98 & 22.3 & 1.69 & 372.3 & 24.2 & 275.5 \\
\hline & 多肥十たい肥 & 4.5 & 3.9 & 0.07 & 1.33 & 19.8 & 2.29 & 678.9 & 27.0 & 285.6 \\
\hline & 標 準 施 肥 & 4.9 & 6.6 & 0.18 & 3.07 & 17.1 & 5.29 & 738.2 & 16.5 & 146.7 \\
\hline & 標肥＋たい肥 & 4.8 & 6.5 & 0.20 & 3.32 & 16.8 & 5.72 & 769.4 & 17.5 & 137.8 \\
\hline & & 4.4 & 8.4 & 0.16 & 3.02 & 18.4 & 5.21 & 766.4 & 24.2 & 249.8 \\
\hline & 多肥十たい肥 & 4.4 & 7.0 & 0.23 & 3. 18 & 18.6 & 5.48 & 744.6 & 32.5 & 502.9 \\
\hline
\end{tabular}

理による化学性の変化は表 5 のごとくであり，たい肥施 用によって各成分とも增扣する傾向が叔られ，有效㦔》 ン酸は多肥区に多く、これにたい肥を加えるとさらに增 加する傾向を示した。秃心置換性石灭も多肥十たい肥区 に多い傾向を示した。

以上の上5に抜根後の土壇処理，るいは定植後の肥 培処理によって，土壤の理化学的性質は相当変化してい ることが認められた。一方かかる状態下における定植苗 の生育状態は図 $1 ， 2$ のごとくである。すなわり，1962 年 4 月定植した苗は，2年間にわたって摘採，せん枝な どを行なわず，放任状態においてその間の生育状況を調 查した。図1に示した土埕処理による茶の生育状況で は，樹高の場合，植之付初期には，無処理应と比較して 混層耕，深耕両区はややまさったが，天地返し区は無処 理区よりやや少った。その後 2 年目にはいると，各処理 区はいずれも無処理区よりまさったが，定植初期同梾混 層耕，深耕区等がすぐれていだ。つぎに翰の太さについ ても，樹高とだいたい同様の傾向で，天地返し区の場 合, 定植初期の生育はやや劣る上5で, 2 年目にはい。 て無処理区上りすぐれてはきたが，他の処理区伍ど生育 はお5盛でない。さらに着葉数，分枝数などについても 樹高, 幹径とだいたい同様の傾向を示し，天地返し区は 定植 2 年後には無処理よりまさるものの, 混層耕, 深耕 区上り劣る傾问が強く，下層土の表層への移行に上る土 壤の肥よく度の低下が，この場合がかなり影響している ものと思われる。

つぎに図 2 に示した肥培処理による茶の生育状況につ
いては，樹高，幹径，葉数あるいは分枝数など各調查項 目とも定植当年は処理区間に渒とんど差がなく，2年目 にはいって, 樹高, 幹径では標肥十たい肥区, 葉数, 分 枝数では多肥+たい肥区などがすぐれ，たい肥施用の効 果が大きいようであっだ。

以上の上5に土埕処理および肥培処理別にみた茶苗の 初期生育は土裹処理の場合，深耕，あるいは混層耕区の 生育が良く，肥培処理十たい肥区がまさるようであっ た。第 3 年目にはいった 1964 年以降は摘採を行ない, 茶 芽の生育，収量および茶の品質を調查した。その結果は 図 3・4 に示すごとくである。図3に示した土壤処理を 買にした場合，芽数では無処理区と比较して各処理区は いずれもまさる傾问を示したが，各処理区間についてい 年によって多少傾向が異なり，1966〜67年にかけては天 地返し区か，1968年にはいってからは混層耕区が孛さっ ていた。また，百芽重については各処理区間の差が少な く，年によって一定の傾向がみられなかった。

収量については，ほとんどの瑒合，各土壤処理区は無 処理区より多収であったが，処理区についてみると，定 植 $3 \sim 4$ 年目の 1965年ごるまでは深耕区が り，下層土が混入した混層耕，天地返し区ではその効果 は著しくなく，定植後 5 年 (1966年) 経過してようやく 混層耕，天地返し区の収量が增加してきた。

一方，各土壤処理に上る紅茶の品質については，定植 $3 \sim 4$ 年目までは収量の少なかった天地返し区がまさ り，その後む他の姏理区と比較して良好な場合が多かっ たが，茶期によってその傾向が变動しており，明確では 
図 1 土塞処理による茶の生育状況
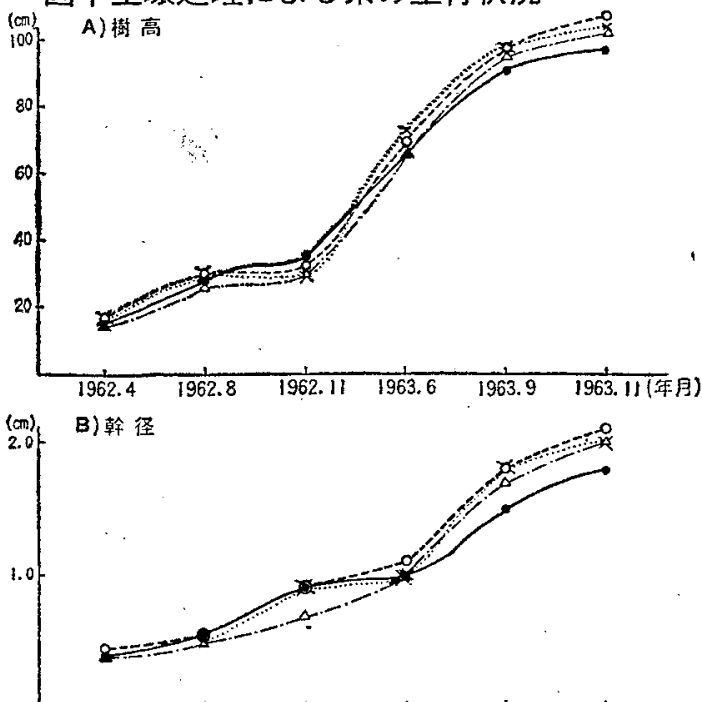

$\begin{array}{llllll}1962.4 & 1962.8 & 1962.11 & 1963.6 & 1963.9 & 1963.11(\text { f月月) }\end{array}$
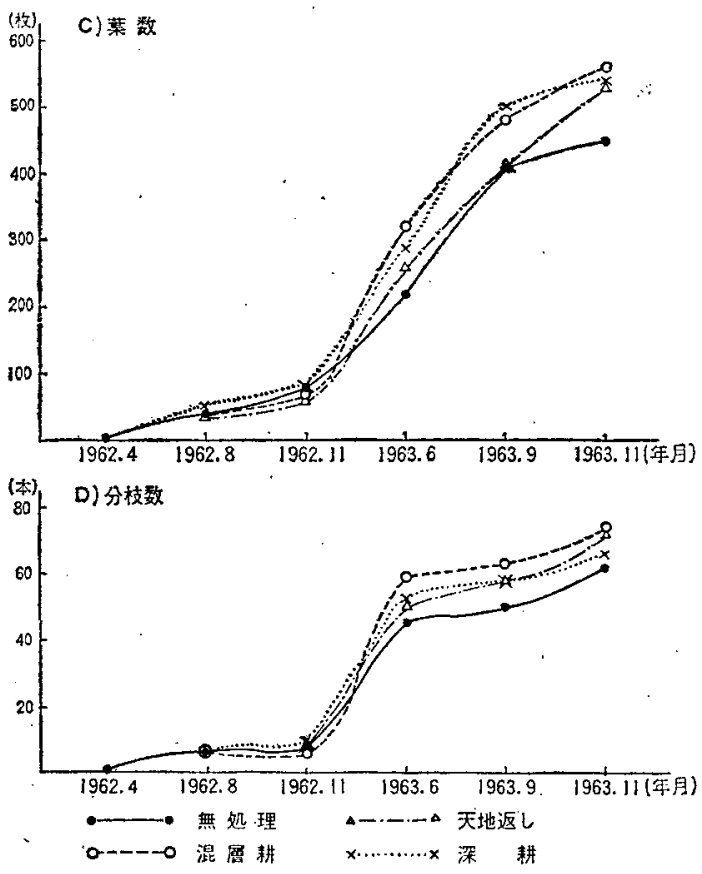

図2肥培処理による茶の生育状況
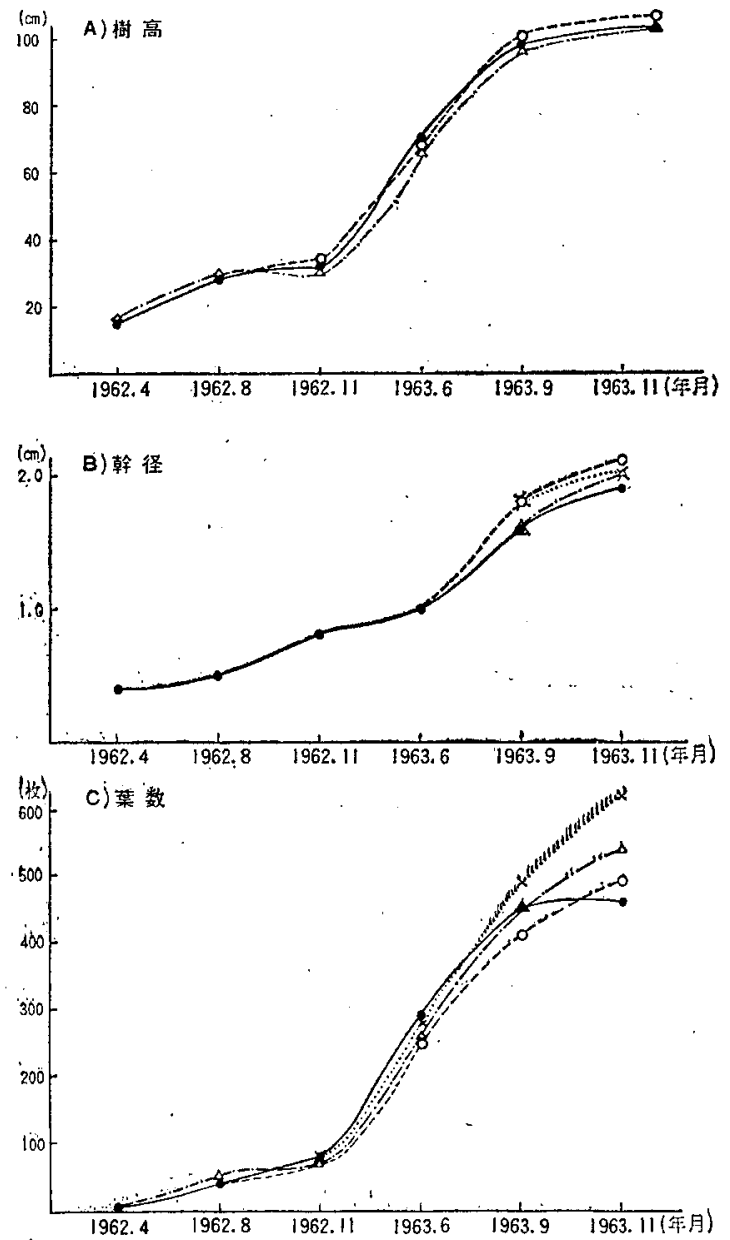

D) 分枝数

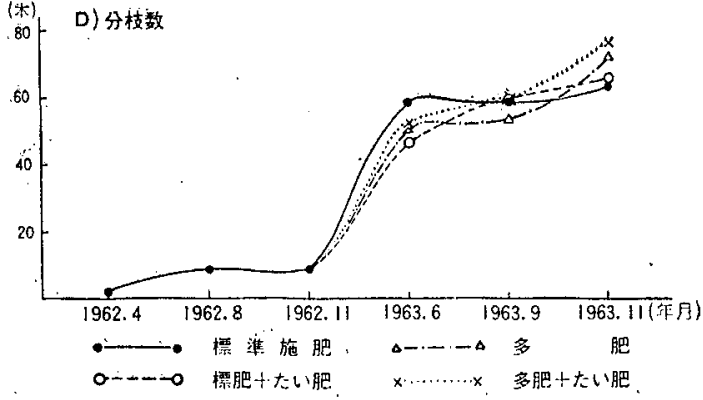


図3土倳好理による芽の生青、茶の品質への影堷
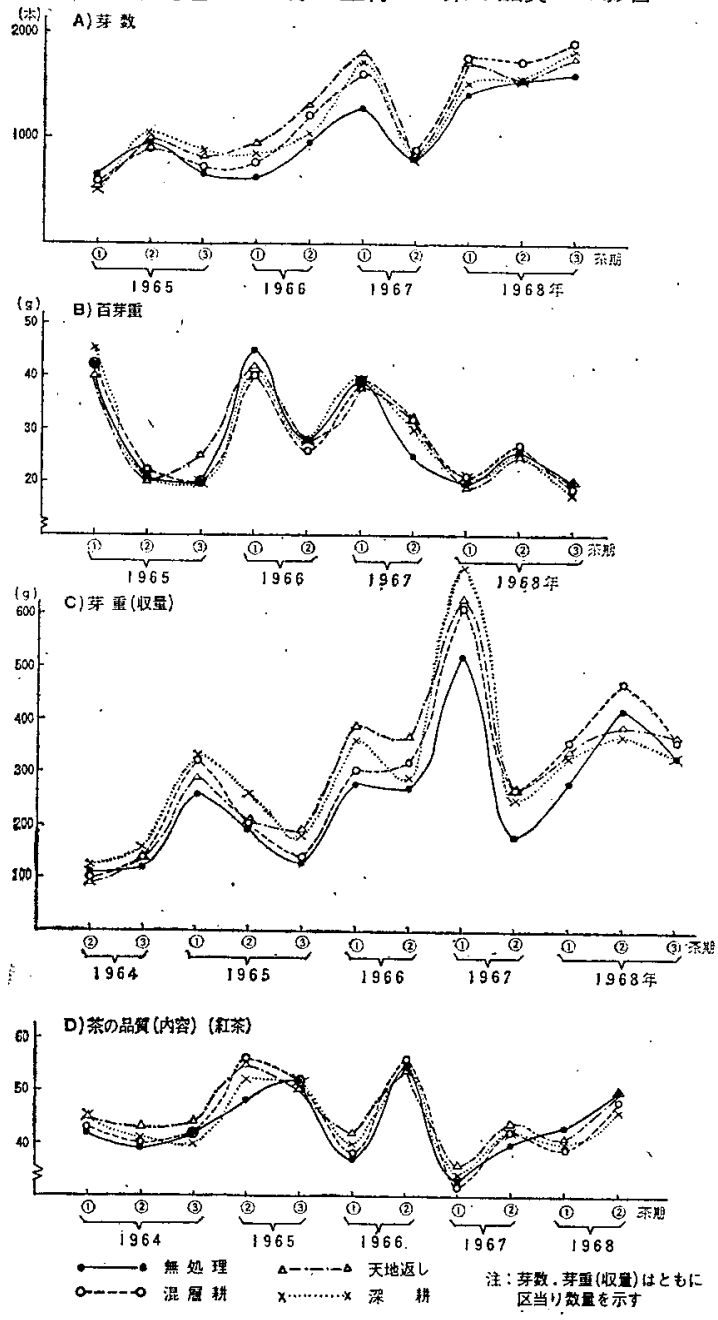

ない。

以上のよ5に土壤好理別にみた場合, 芽の生育あるい は品質えの影響はそれねど顕著ではなかったが，図4に 示した定植後の肥培好理別では，芽数，百芽重など，標． 肥，多肥ともにたい肥施用区がをさっていた。その結果， 収量についても，標肥区と多肥区との差はそれはどでは ないが，それぞれのたい肥施用区の収量はかなり上回わ っており，1968年にはいって多肥十たい肥区の收量は他 区を大幅に上回わった。一方，紅茶の品質は，最近では 各炕理区間に差がみられないが，定植初期の1964年ごる には多肥区の品質は標肥区上り劣っていた。
図4肥培処理による芽の生育，茶の品質への影響
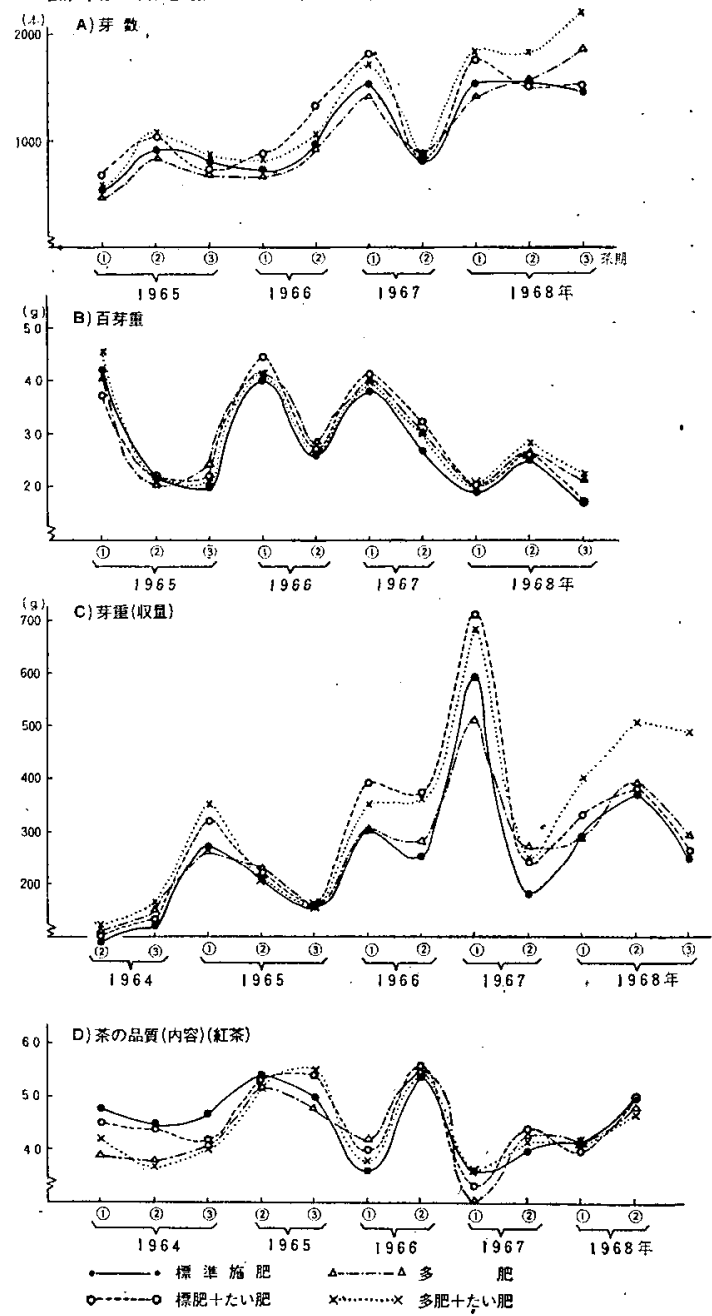

このよ5に改植前後における土壤処理および肥培処理 が菜芽の生育あるいは茶の品犋に対する影響は, 土壤処 理よりも，定植後の肥培好理の泀らがをの影響が大き く、特にたい肥施用の勃果の大きいことが判明した。な お，これらの処理に関連して雑草の発生状態, 土燷水分 の動態等にもかなり変化がみられた。さらに，1967年1

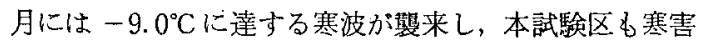
を起し，袙変葉を生じたが，好理の種別によって被害状 況にかなりの差がみられた。その調査結果を示すと表 6 のごとくである。その結果，土壤処理別にみた場合，い ずれ女上位葉の被害が激しく，下位葉になるにつれて被 
表 6 各処理による寒害抵抗性(被害率)の差異

A) 土壤処 理

\begin{tabular}{|c|c|c|c|c|c|c|}
\hline 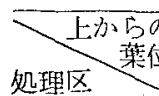 & & 第。 & 第 3 菜 & 第 4 葉 & 計 & 平均 \\
\hline 処 & $15.0^{\%}$ & 7.6 & 6.5 & 5.4 & 34.5 & 8.6 \\
\hline 混 㢞 耤 & 井 10.0 & 5.1 & 4.7 & 1.9 & 21.7 & 5.4 \\
\hline 天地返 l & 14.8 & 11.9 & 10.9 & 8.7 & 47.3 & 11.6 \\
\hline 深 & 9.3 & 3.4 & 2.7 & 2.2 & 17.6 & 4.4 \\
\hline
\end{tabular}

B ) 肥 培 処理

\begin{tabular}{|c|c|c|c|c|c|c|}
\hline 上からの & 第 1 莯 & 第 2 葉 & 第 3 茱 & 第 4 䒹 & 計 & 平均 \\
\hline 標準 施 肥 & 11.2 & 3.6 & 2.8 & 2.5 & 20.1 & 5.0 \\
\hline 標肥＋たい肥 & 11.1 & 5.7 & 1.1 & 0.3 & 18.2 & 4.6 \\
\hline 多盟 & 18.1 & 14.4 & 18,1 & 14.8 & 65.4 & 16.4 \\
\hline 多肥+たい肥 & 8.8 & 4.3 & 2.6 & 0.5 & 16.2 & 4.1 \\
\hline
\end{tabular}

注：1）1区から10枝条を避び，葉位は上から第4 葉まで，4区の平均值で亦す。

2) 被害摔は 1 枚の藮の褐変部の面皘比率として 算出。
害は軽いが，無処理区と比較して淈層耕，深耕の両区は 被害ががいして少なかった。しかし天地返し区は下位 葉にむでかなり被害が激しくでていた。さらに肥培処理 別にみた場合多肥区の被害が激しくでているが，この場 合でもたい肥施用によって被害は著しく軽減されてい る。

以上 7 年間にわたる試験結果から改植時に深耕，混層 耕あるいは天地返しなどの土壤処理を行ならことによ り，無処理と比較して，その樹勢を強め収量增を期待与 ることができるが，混層耕，天地返しなど化学性の劣る 下層土を表層に出した場合には，やや乾燥しやすく，初 期生育の劣る傾向が女った。しかし定檩後の肥培処理方 法では，多肥あるいはたい肥施用が有効で，特にたい肥 施用の効果はかなり顕著である。したがってかかる肥培 処理を組み合わせることにより，改植後の早期成園化を 図ることが可能であると考えられる。なお，かかる土壤 ならびに肥培処理により，根張りもかなり異なってお り，長期に放たる樹勢の維持，增進に影響するものと思 われるので，今後は根群の状態を調查して，この試験を 完結したい。

\section{溝式深耕法と埋込夕材料}

\section{福岡県立農試茶業指導所 青木彦二・坂田寿生・神屋勇雄}

1 むえがき

近年，産業界の発展はめざましく，経済は高度成長を きたし，その影響を茶業界も受け，茶業経営は目をみは， るばかりの成長をしている。このような背景の中で農家 の新植，改植の意欲は盛んであり,これと平行して国，県 の事業として行なわれている棰造改善事業、パイロット 事業等が盛ん汇行なわれているのが現状である。咋年の ような異常干ばつや長雨に上る渦湿の害も考元られ，新 植，改植に当っては，いるいると閭兔があると思われる。 今回は茶樹を定植する前の土壤処理が収量, 製茶品質,

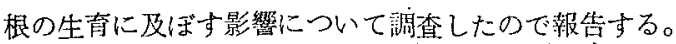
2 成綪々考察

(1) 試験区㧍よび土㙵処理断面：この試験を遂行する に当たって，次のような試験区を設定した。

○試 験 区

1 区 粗犬゙類埋込み区
竹・木等太いものを最下部に並ベ，粗だ類を土壤と交 互に投入した。

2 区 粗石れき埋込及区

$10 \mathrm{~cm}$ 以上のグリ石を最下部に並べ，その上にジャリを 土壤と交互に投入した。

3区天地返し埋込み区

掘った土埪を上下入れ替える。

4 区 対照 (無深耕) 区

○土壤知理断面图 (次頁参照)

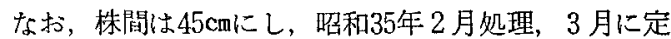
植した。

\section{○根系调查法}

1 区，3本を区画法 $(22.5 \times 30 \times 20 \mathrm{~cm})$ によってて壌 とともに根を掘り上げ，水洗法によって根をふるい分け し，下記のよ5に分類し，乾燥してひょう量した。細根 $2 \mathrm{~mm}$ 沫満, 中根 $2 \mathrm{~mm}$ 以上 $10 \mathrm{~mm}$ 末満, 太根 $10 \mathrm{~mm}$ 以上。 
土壤処理断面図

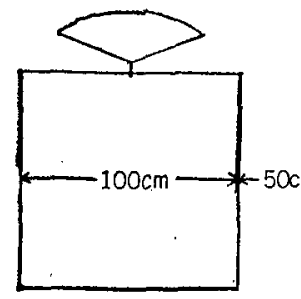

無 深 耕

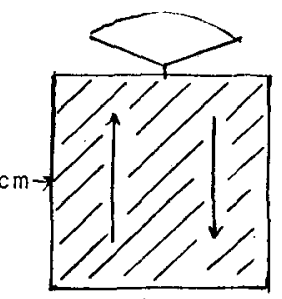

天地返儿
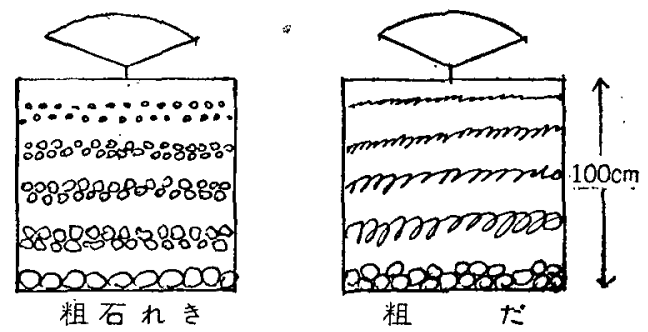

（2）生葉収量および制茶品質 :

○生葉収量 (年次別，各年度は一，二，三番茶合計） $\mathrm{kg}$

\begin{tabular}{|c|c|c|c|c|c|c|c|c|}
\hline 陚駩区 & 37 年 & 38 年 & 39 年 & 40 年 & 41 年 & 42 年 & 合 計 & 指 数 \\
\hline 粗 だ 区 & 128.0 & 291.0 & 485.8 & 717.7 & 1225.4 & 1389.4 & 4237.3 & 104.5 \\
\hline 粗石れき区 & 119.0 & 253.0 & 454.8 & 637.5 & 1180.1 & 1318.8 & 3963.2 & 97.7 \\
\hline 天地返し区 & 114.0 & 268.0 & 462.7 & 665.4 & 1192.0 & 1341.4 & 4043.5 & 99.7 \\
\hline (対照)区 & 1.22 .0 & 274.0 & 514.8 & 682.3 & 1197.3 & 1265.1 & 4055.5 & 100.0 \\
\hline
\end{tabular}

○製茶品澌 (形状, 色沢, 香気, 水色, 滋味20点法合計) (一番茶のみ)

\begin{tabular}{|c|c|c|c|c|c|c|c|c|}
\hline 試䍄 区 & 37 年 & 38 年 & 39 年 & 40 年 & 41 年 & 42 年 & 合 計 & 指 数 \\
\hline 深 耕 粗 だ 区 & 90.8 & 91.0 & 96.5 & 93.0 & 95.6 & 95.5 & 562.4 & 96.6 \\
\hline 粗石れき区 & 98.8 & 90.5 & 98.5 & 98.5 & 98.3 & 98.0 & 582.6 & 100.1 \\
\hline 天地返し区 & 95.5 & 97.5 & 96.0 & 96.5 & 96.3 & 95.0 & 576.8 & 99.1 \\
\hline (対照) 区 & 97.8 & 99.5 & 97.0 & 96.5 & 97.9 & 93.5 & .582 .2 & 100.0 \\
\hline
\end{tabular}

今までの試験結果を集約すると生葉収量では粗だ類埋 込み区がよく，次いで無深耕区となったが，成園化する につれて土壌処理区がよくなってきた。このように無深 耕区が比較的よいのは，表土が40c近くあったことと， 定植初年度に土墒処理区が乾燥にあったのに対して，無 深耕区は乾燥にあわなかったことなどが影響しているも のと思われる。しかし，年を経るに従って，土壤処理区 は生育がよくなって，成園化するころには，無深耕区上 りも生葉收量が多くなった。特に干ばつに対しては無深
耕区は根が浅いため弱いよらであり，粗石れきを投入し たものも，やや，乾燥に弱いようである。昨年のような 干ばつの年は二, 三番茶への影響が激しいよらである。 また，茶の品質では，初期には無深耕区がよかったが， 年を経るに従って土壤処理区がよくなりこの中でも粗 石れきを投入したものがよくなった。この区は沖皘層を 仮定して作ったのであるが，期待したほどの品質向上に は、ならなかった。

(3) 根柔調查

○地上部と地下部のバランス ( 3 本の平均值)

\begin{tabular}{|c|c|c|c|c|c|c|c|c|c|c|}
\hline \multirow{2}{*}{ 試 } & \multicolumn{2}{|r|}{ 地 } & \multicolumn{3}{|c|}{ 部 } & \multicolumn{2}{|c|}{ 地 } & \multicolumn{2}{|c|}{ 下。部 } & \multirow{2}{*}{$\mathrm{T} / \mathrm{R}^{\text {率 }}$} \\
\hline & 樹 高 & 株 幅 & 幹茎乾重 & 葉乾䨓 & 地上部計 & 細根乾重 & 中根乾垂 & 糧大根乾国 & 白地下部計 & \\
\hline 粗だ類埋闸 Х & $73.0^{\mathrm{cm}}$ & 130.0 & 1482.7 & 324.7 & $\begin{array}{r}\mathrm{g} \\
1807.4^{2}\end{array}$ & \begin{tabular}{r|}
$\mathrm{g}$ \\
523.05
\end{tabular} & $170.73^{g}$ & $\begin{array}{r}8 \\
427.89\end{array}$ & 1121.67 & \\
\hline 粗吕れき埋込み区 & 70.0 & 130.0 & 1313.7 & 340.6 & & & 154.32 & 364.28 & 1133.99 & 145.9 \\
\hline 天地返し区 & 71.0 & 129.0 & 1186.0 & 271.4 & 1457.4 & & 216.10 & 227.17 & & 148.8 \\
\hline 深 耕 & 73.3 & 131.3 & 1445.9 & 337.9 & & & 199.30 & 283.88 & 957.23 & 186.4 \\
\hline
\end{tabular}


○総根の垂直分布 (\%)

\begin{tabular}{|c|c|c|c|c|}
\hline 深さ 区 & 1 区 & 2. 区 & 3 区 & 4 区 \\
\hline $0 \sim 20^{\mathrm{cm}}$ & 57.8 & 64.4 & 47.5 & 57.9 \\
\hline $20 \sim 40$ & 28.2 & 21.9 & 23.1 & 24.0 \\
\hline $40 \sim 60$ & 13.7 & 15.0 & 13.3 & 11.0 \\
\hline $60 \sim 80$ & 9.9 & 8.9 & 8.8 & 4.9 \\
\hline $80 \sim \dot{\sim}_{100}$ & 7.5 & 8.2 & 9.9 & 2.2 \\
\hline 計 & 117.2 & 118.5 & 102.6 & 100.0 \\
\hline
\end{tabular}

○細根の重直分布 (\%)

\begin{tabular}{|c|c|c|c|c|}
\hline 深さ 区 & 1 区 & 2 区 & 3 区 & $4 区$ \\
\hline $0 \sim 20^{\mathrm{cn}}$ & 41.4 & 52.2 & 35.2 & 48.1 \\
\hline $20 \sim 40$ & 23.7 & 31.8 & 31.4 & 24.1 \\
\hline $40 \sim 60$ & 17.6 & 18.6 & 16.2 & 15.3 \\
\hline $60 \sim 80$ & 14.5 & 13.9 & 14.3 & 8.7 \\
\hline $80 \sim 100$ & 13.0 & 13.4 & 16.6 & 3.8 \\
\hline 計 & 110.2 & 129.9 & $\cdot 113.7$ & 100.0 \\
\hline
\end{tabular}

根系調查にあたって，端から３本を番外で抜いて 4 本 目から順次了本調査したが，かなりの生育差があった。 なた，無深耕のとこるでも前にあった雑木か松の根が深 くはいっていたよ5な場合，この部分に根がよく伸びて おり，完全な無深耕状態と言えなかった。地下部の水平 分布を太根、中根, 細根についてみると太根は，らね間 に当たる部分には少なく，株先に多い。中根は株を中心 に15〜45cmの個所に多く，細根は太根とは逆に，5水間 に当たる部分に多くなっており，土裹処理間には，各根 とむ差は少ないよ5である。また、地下部の垂直分布を みると太根は粗石れき区が80〜100 cm屯ではいっており， 粗だ，天地返しの順によく；中根は天地返し，粗だ，粗 石れきの順に深くはいっており，この三土壌好理間では 大美はなかった。細根は量的には粗石れき，天地返し， 粗だの順になっていたが，いずれも $80 \sim 100 \mathrm{~cm} の$ 所まで, 上く伸びており，この個所では無深耕区の3〜4倍の細 根があった。無深耕区は上層 0〜30 cm の部分に根が多く 集むっているため干ばつには弱いよである。また，地 上部と地下部のバランスについてみるとやはり土壤処理 を行なった区がよくなり，粗不れき、天地这し，粗だ， 然深耕の順となる。以上のよ5に土塿処理を行なったは らが明らかに潹くはい。ており，今後の樹勢維持のため にも深耕を行な5必要がある。

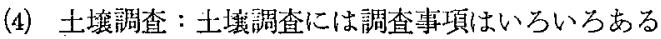

と思われるが根との関係が深いと思われる三相分布およ び土堙硬度について調査した。なおこの試験に供試し た土境は洪積磻で上層は C L，下層はH Cであり粘質土 壌であった。まず，三相分布についてみると0〜40cm の 部分では土塆処理区と無深耕区ともに変わらなかった。 これは無深耕区にはさきに述べたよ5に表土が40cm近く あったためであると考えられる。また，40cm以下になる と土壤処理区と無深耕区との美が明白となり，土壤処理 区のほ5が固相に比し液相，気相の占める割合が多いの に対して，無深耕区は固相に比し液相，気相の占める割 合が少なくなっていた。次に，土㙋硬度についてみると 土壤処理区は 0〜60cmで 8〜 18, 60cm 以下で 14〜16であ るのに対して，無深耕区は 0 60cmで 11〜23，60 cm以下 で23〜26となり，土壤処理区との差が明らかに認められ た。土壤処理間でも粗石れき，粗だ、天地返しの順とな った。以上の上うに，土壤処理を行なった活らが根が深 くまではいっており，土猿状態む上いので，定植前の深 耕がいかに必要であるかがよくわかるものと思われる。 3 むす び

この試験では集約的な栽培も考え、品質の向上をねら って、粗だ，粗石れきの混入を試みた。しかし，新植， 改植無行な5場合は人力による開壁は考えられず，機械 力，特にブルドーザーによる開園が行なわれているのが 現状である。したがってここようにブルドーザーによ る開園の場合には粗だ，粗石れき等を投入することは困 難なよ5に思执狆るので，天地返しのような土㖶を上下 反転する方法が好ましいよ5に思われ，深耕の深さは試 験結果を見ても明らかなよ5に $1 \mathrm{~m}$ 程度の深耕を行なっ て㧍く必要があるよ5に思われる。これはさきにあ述べ たように干ばつ等に対しても抵抗力が強くおう盛な樹 勢を維持することができると舁われる。定植後は乾燥防 止に十分注意を厸って，10 a 当だり少なくとも $1,000 \mathrm{~kg}$ 程度の敷わらをする必要があるものと思われる。さきに も述べたよ 5 に開園する場合は；ブルドーザーによる 1 $\mathbf{m}$ 程度の哚耕がよいが，現在のブルドーザーは深さ $60 \mathrm{~cm}$ 程度の梁耕しかできないのが契状であり，今後 80〜100 c⿴囗十程度の深耕ができるようなブルドーザーの利用が急 務のよ5に思われる。また，開園に当たっては，士壤処 理，特に深耕に注惉しなければならないが，深耕しても 水がたまるよ5であれば根は閭ってしま5ので、排水に は特に注意を执わなければならない。その他，改植の場 合の土壤消毒, 土壤浸食対策，士地利用率等十分検討を 加えた上で，開園を行なら必要があると思われる。 


\title{
連絬式大型製茶機の経済性
}

\author{
一一共同製茶工場の事例分析一
}

\section{三重県農業試験場 增地良之・庄山孝義・松井 久}

はじめに県内の茶産地では, 荒茶加工付加西値尔の取 得と，農業労働力の流出に対応して製茶機械の大型化が。 急激に普及している。そこで大型製茶機の経済性につい て検討するため, 連結式大型製茶機（2セット・50kg粗 揉機 4 台) を導入した鈴鹿市深海地区の農事組合法人深 海製茶組合の経営荚態調查を行なったので, その結果を 報告する。

\section{三重県の茶産地は，生産指向目的により地域区分する} と，南勢の中山間地帯に展開する優品茶生産を指向する 地域と, 北勢鈴鹿山麓の丘陵地帯に展開する面積支配の 量産指向をとる地域に大別することができる。調查対象 とした組合は，後者の地帯にあり，かつその資料はおも に42年度のものである。

深溝製茶組合の概況：同組合は，昭和40年に農業棈造 改善事業により，農事組合法人として発足し，41年から 組合員 (一部組合員外) より生葉を購入し, 荒茶加工・ 販売を行なっている。組合構成振家は，組合設立以前に 製茶工昜を所有していた農家 4 戸，生葉壳り主体農家20 戸，計24戸から構成されている。組合員 1 戸当たり平均 耕地面積は $189 \mathrm{a}$ て比較的大きく，その内訳は，水田99 a，普通畑 $37 \mathrm{a}$, 茶園59 a (成園のみ)，となっている。 製茶工場は農業構造改善事業の近代化施設として建設さ れたものである。

租合の資産内容は, 42年度末で総額 1 , 300万円円で, を の 69\%が建物・機械などの固定資産である（ただし建 物・機械の補助金分 735 万円だけは压綰記帳されてい る)。建設に要した費用は，長期借入金・補助金・出資 金によりまかなわれているが，この種組合としては出資 金が綾額の30\%と比較的多い。出資金は，当初構成農家 1 戸当たり 3 万吅の平等制当てと，茶園面積（当時成園 のみ対象＝13ha） 10 a 当たり 1 万円からなり，さらに 42 年度に，生葉置場增設々一部機械・器具購入のため 249
万円の增資が 41 年度の個々の農家の生葉出荷寒績に応じ てなされている。

組合の運営は, 役員 7 名を選出 $し$, 組合長・副組合 長・書記・会計などの職務が分担されている。工場労䅂 は，一部職工労務を組合員外から雇用する以外は，すべ て組合員によりまかなわれている。職工労務の職務の範 团は，蒸機から乾燥機までで，蒸機 1 名，粗揉機から乾 燥機まで 2 名, 合計常特 3 名で 1. 日 2 交代 (12時間学 務)がとられている。生葉の受け入れ，製品の出荷準備 などの雑労務は，職工学務者を除く組合員の輸番制で, 平等出役がとられ，毎日 4 〜 人が出役している(おす に咺間)。

42年度の工場の稼動状況は，春番 3 月14日〜22日（21 日休日），一番茶5月19日～6月 7 日，二番茶7月14日 〜30日, 総稼動日数45日で, 5ち尽夜24時間榢動した日 が34日るり，総稼動時間は. 973時間である。製茶の中心 でむる-番茶の開始時期が，他の地区に比較して10日〜 2 週間もおそい。これはこの地区の気象上の理由にもよ るが, それょりも,この地区は, 辟業経営中水田の占め る绑合が高く，水稲の田植期に規制されること，さらに この地区は生葉売り主体の最家が多く，生葉の量産体制 をとる茶の経営慣習から拔けきっていないためと思われ る。

経営夹續と成果：42年度の生葉の購入および荒茶の販 売状沉を示したのが裴1である。組合員からの生菜の出

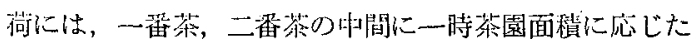
割当て制がとられている。生染の購入何格は，はとんど が日割り制で，その決定は鈴鹿市の茶業協議会の基準洒 格に準じて役員会によりきめられているが，喫除に支払 われている金額は，一応生葉出荷時に基準価格に応じて 概算払いがされ，さらに決算特に收支決算の状況に応 じ，精算払いがされている。42年度は，一番茶および二

表 1 生葉購入及荒茶販壳状況 S 42 年

\begin{tabular}{|c|c|c|c|c|c|c|c|c|c|c|c|c|}
\hline \multirow{2}{*}{ 区 } & & \multirow{2}{*}{ 分 } & \multicolumn{2}{|c|}{ 生 } & 受 & \multicolumn{2}{|c|}{ 高 } & \multicolumn{2}{|c|}{ 製 品 } & 販 & \multicolumn{2}{|c|}{ 䒕 高 } \\
\hline & & & 数 & 量 & 金 & 額 & 平均値 & 数 & 量 & 金 & 額 & 平均值 \\
\hline 春 & 番 & 茶 & \multicolumn{2}{|c|}{$22,437.7 \mathrm{~kg}$} & \multicolumn{2}{|c|}{$1,232,640$ 円 } & 55 & \multicolumn{2}{|c|}{$8,460,0 \mathrm{~kg}$} & \multicolumn{2}{|c|}{$1,584,001 円$} & 187 \\
\hline- & 番 & 茶 & \multicolumn{2}{|c|}{$116,978.5$} & \multicolumn{2}{|c|}{$8,546,321$} & 73 & \multicolumn{2}{|c|}{$26,898.0$} & \multicolumn{2}{|c|}{$10,148,612$} & 377 \\
\hline$=$ & 番 & 茶 & \multicolumn{2}{|c|}{$103,580.0$} & \multicolumn{2}{|c|}{$4,817,296$} & 47 & \multicolumn{2}{|c|}{$25,241.5$} & \multicolumn{2}{|c|}{$6,648,959$} & 263 \\
\hline 合 & & 計 & \multicolumn{2}{|c|}{$242,996.2$} & \multicolumn{2}{|c|}{$14,596,257$} & 60 & \multicolumn{2}{|c|}{$60,599.5$} & \multicolumn{2}{|c|}{$18,381,572$} & 303 \\
\hline
\end{tabular}




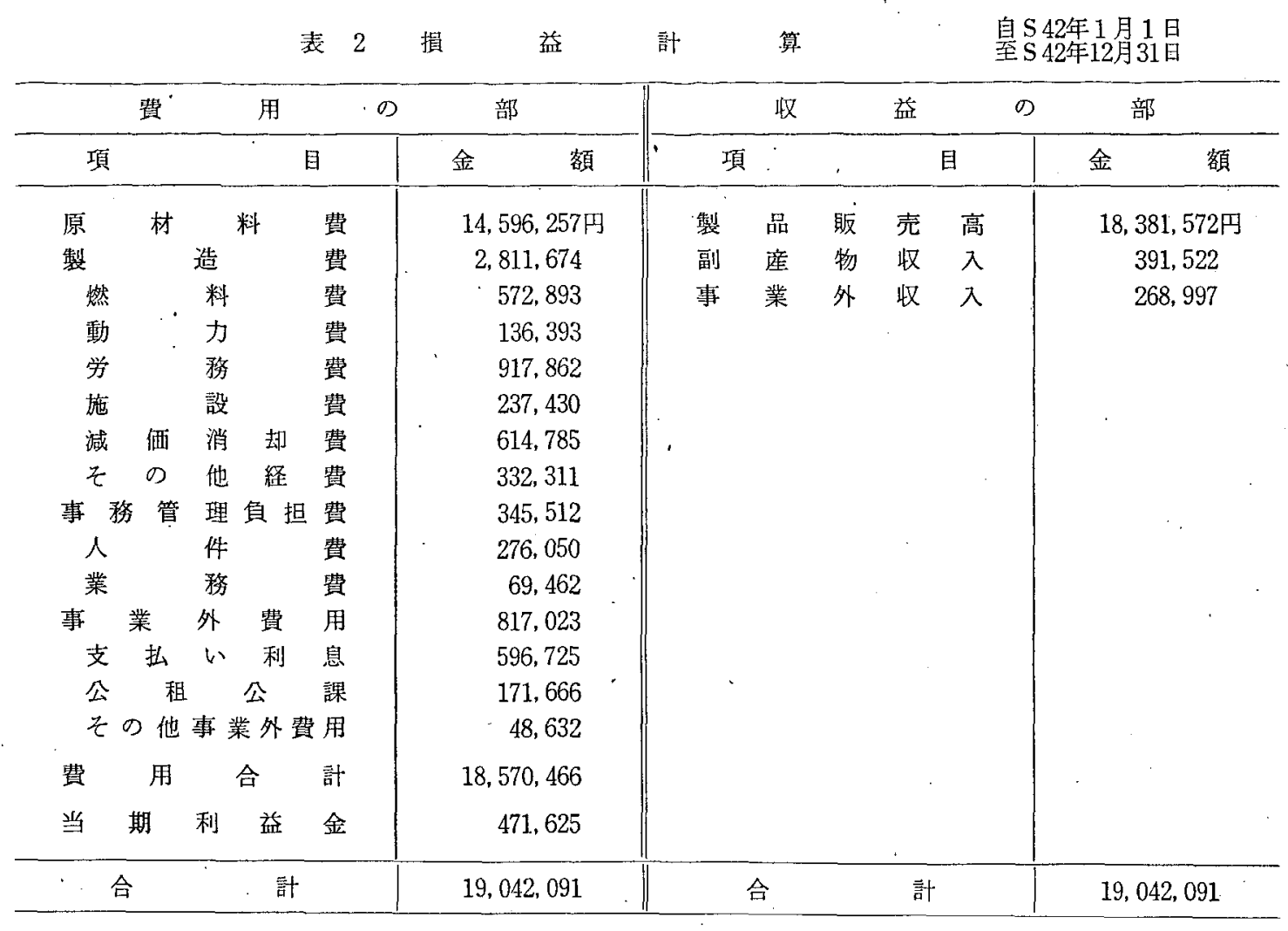

番茶に対し, 生葉 $1 \mathrm{~kg}$ 当たり 5 円の精算払いがされてい る，荒茶の販壳は，四日市市の茶商拉よび地元の茶市場 を通じて行なわれ，42年度は洼とんど生産と同特に販売 されている。

経営の成果を示したのが表2である。まず費用の部で は，生葉を一括購入しているた如，原材料費が全体の79 \%を占めている。燃料費はガスおよび重油代 (A 重油) で,ガスは 1 本 (50kg入り) 1,450月，重油は200も入り 1,800円で，大量購入のため一般市俩より安い。動力費 はすべて電気代である。労務費は，時間当たり単洒を職 工労務と雑労務にわ忛, 42 年度の時間当たり労貨は, 職 工労務220円（ただし春番および一部の人に対しては200 円），雑学務は125円で支払われている。職工労貨の単 洒は，この地区の標準侹格上りやや高く支出われている が，雑労務は 1 日 8 時間学働で 1,000 Pであり，他の日 雇い労働と比較すると安い。なお、この工場の年間学働 洔䦓は, 職工学務 3,006時間，雑学務 2,184時間，合計 5,190 特間で，労俉時間 1 時間当たりの荒茶加工量は $11.7 \mathrm{~kg}$ で，これは周辺の従来の製茶機工場に比較して 4 倍前後の能力である。(なお工場稼動 1 時間当たりの荒 茶加工量は $51 \mathrm{~kg}$ である)。施設費は，一部新しい機具の 導入と工場の修理費である。減価償却は, 耐用年数を建 物26年, 機械器具小すべて 8 年として計算されている。 ただし既述したように，補助金分（建物 3,652 千円，機
械3,698千円）が、生縮記帳 されているので，減価償却費 はその分 $(542,440$ 円) だけ少ない。その他経蔶は，荒 茶の荷造り・出荷および一部生葉の集荷などに要する費 用である。事務管理負担費のらち，人件費のおもなもの は，役員に対する報酬である。

次に収益の部は，荒茶貶売高は 1,800万円で，副産物 収入は昐茶である。事業外収入のおむなものは，製茶期 間外の生葉置埸の儥貸し料である。

この組合は，42年度に47万円の当期利益金を得て，出 資金に対する配当金（年6 分）を支払っている。な㧤 茶10kgの生産監は656円で，これは他の製茶工場の荒茶 生壁費と比べると安い。

経営分析諸指標：この組合の若干の経営分析諸指標を

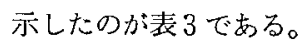

財枒諸指標では，自己資本比率は工場建設に要する費 用の多くを他人資本（制度融資）に依存しているため低 い。固定比率は，資産の多くが建物・機械なぞの固定資

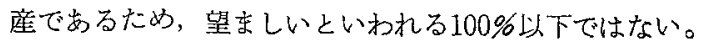
しかし流動比率は，短期借入金が注とんどなく，望まし いといわれる 200\%以上で，経営は安定しているといえ 上5。

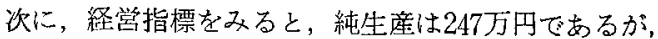
この組合では既述したように生葉の購入代金を精算払い で，一番茶・二番茶に対し，各々生菜 $1 \mathrm{~kg}$ 当たり 5 円を 
表 3 経 営 諸 指 標

経営分析諸指標

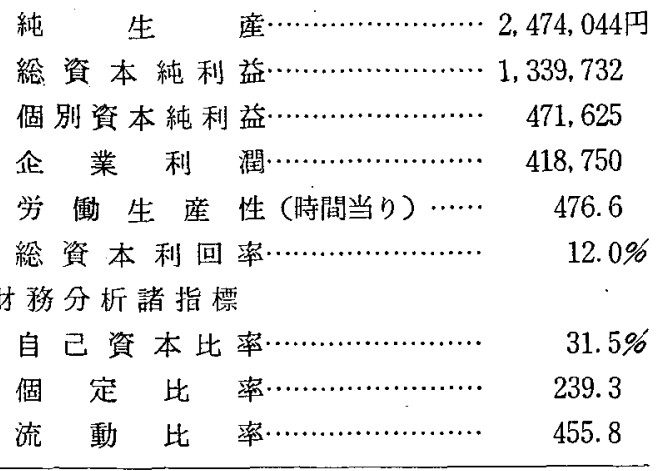

加算している。これは生葉の出荷分に対する利益配分と いえる。そこでこの分 (110万円)を純生産分として加 算すると 357万円となる。なおこの組合は, 企業利潤を” あけ゚，労㗢生産性も高く，さらに資本利回りは 1 割以上 になるなど工場の効率は高いといえる。

総括 : 最後に，荒茶加工に上る付加価值分について検 討する。既述したよ5に，一番茶・二番茶への利益配分 の形で支払われた分をむ加算して，付加価値分(純生産) は357万円で，これの配分方法は，まず生葉へ約 110 万 円，労貨分として支払われた分が 119万円，支払い利 息・公租公課77万円, 利益金として4i万円で, 利益金の 5ち30万円が出資金に対する配当金として支执われてい る。今, 荒茶加工による付加価値分を生葉 $1 \mathrm{kgk}$ にいて 換算すると14.7円で, 茶園10aにすると23,686円，組合 構成農家 1 戸当たり149,035円となる。
表 4 三重県多気郡大台町M製茶工場の 経営諸指標

（粗揉機 $50 \mathrm{~kg} \cdot 35 \mathrm{~kg}$ 各 1 台 $\mathrm{S} 42$ 年度実績）

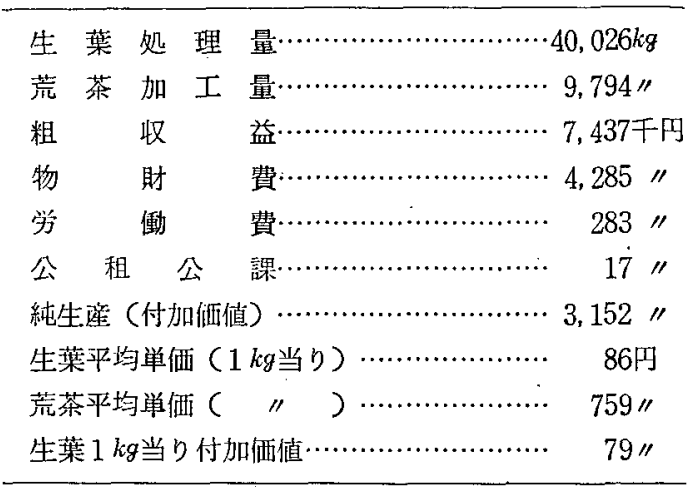

これは榎品茶加工工場に比較すると棐常に少ない(表 4 参照)。しかも製茶事業を行ならことで, 出役労務は 負荷され，これが個別の茶作に影響する不利，むるいは 製茶機械の稼動に合虬せ摘採を行ならことによる損失 などを考えると，製茶による有利性が低くなる。このよ らに付加価値の少ないことは, 現在の生葉の高㜀による ためか，あるいは品質の悪い茶の加工によるためか，ま た付加価値が少ないことが本質的なことであるならば, 大型共同製茶工場の意味は，(1)製茶学慟の確保, (2)品質 向上の機会を与える，(3)立荒茶とい5商品を多量に集 める機会をむち、その結果有利に販売できることになる と云5のか、これらが今後に残された問題である。

最後に，この調查に終始ご協力をいただいた深海製茶 組合長酒井孝氏に深く感謝する。

\section{京都府に招ける茶業経営実態の分析}

1 はじめに

この調査を取り上げた動機

（1）京都府における喱業の5ち，茶は歴史的代表特应 物であるが；その生産方式は慣行経験技術により個別的 で零細な自家労作の集約経営がなされてきた。しかし近 年社会経済情勢の大きな変動で罢業労働力は払底し，こ れに対応して茶の生産方式む技術開発により近代化され つつあるこらした現状の中で高䄲茶産地としての品質 を保持しながら近代的生産方式に改善するためには，ま ず現状の経営実態のは握が必要である。

\section{京都府立業茶研究所 大 田 昭二}

（2）改良普及員が管内茶業浓家の絽営実態と問題点を は握するため, 破修の一環として府下茶噟地ごとに茶担 当普及員が中心となって，一定の記帳様式に基づいて調 查分析することとした。

2 調查方法および分析方法

(1) 調 查 万 法

京都府の茶はてん茶, 玉露, 煎茶之緑茶の上質茶を生 産するが，今回の調查ではてん茶，前茶について調查す ることとした。

調查農家の邀定に当っては，山城地方では茶を主幹と 